\title{
CORPORATE SOCIAL RESPONSIBILITY AND TOURISM INDUSTRY: STAKEHOLDER APPROACH
}

\author{
Suleiman JAMAL MOHAMMAD \\ Princess Sumaya University for Technology, Department of Accounting, Amman, Jordan, e-mail: s.mohmmad@psut.edu.jo \\ Lara AL-HADDAD \\ Yarmouk University, Department of Finance and Banking Sciences, Irbid, Jordan, e-mail: lara.haddad@yu.edu.jo \\ Muhammad SAFDAR SIAL ${ }^{*}$ \\ COMSATS University Islamabad, Department of Management Sciences, Pakistan, e-mail: safdar.sial786@gmail.com
}

\author{
Peng WAN
}

Zhejiang Gongshang University, School of Accounting, Hangzhou, China, e-mail: wanpeng@zjsu.edu.cn

\begin{abstract}
Citation: Jamal Mohammad, S., Al-Haddad, L., Safdar Sial, M., \& Wan, P. (2020). CORPORATE SOCIAL RESPONSIBILITY AND TOURISM INDUSTRY: STAKEHOLDER APPROACH. GeoJournal of Tourism and Geosites, 30(2spl), 913-916. https://doi.org/10.30892/gtg.302spl18-522
\end{abstract}

\begin{abstract}
In terms of tourism companies, the corporate social responsibility commonly known as (CSR) can be addressed as basic guidelines for tourism business which enable them to assimilate environmental, socio-economic, and political concerns of indigenous people and local businesses in line with their own goals and objectives. In the modern era corporate social responsibility is seen in the context of multiple stakeholders. These stakeholders are not only considered as a beneficiary but also considered as partners in any such activity. Nowadays it has become an integral part of tourism companies' policies and strategies. Its growing importance can be accessed from the fact that over $70 \%$ of research articles on the topic have been published in the last half of the decade. The main focus of this study is the evolution of corporate social responsibility in terms of literature and identifying the potential gaps in the present body of literature from the stakehold er's perspective. Present research mainly takes into account the tourism industry and challenges the earlier approaches adopted by the researchers to assess corporate sustainability by incorporating the latest empirical evidence. The evidence point towards the importance of incorporating the stakeholder's perspective in terms of research. This evidence also stresses the importance of incorporating policies about corporate social responsibility at stages of any tourism business at both the planning and execution level.
\end{abstract}

Key words: Corporate social responsibility, Stakeholders, Tourism, Sustainability

$* * * * * * *$

\section{INTRODUCTION}

In present times with the advent of information technology, people around the world are having started to more and more attention towards corporate and social sustainability. Issues related to environmental pollution, issues regarding waste management, and control along with global warming have become discussion points at all levels of communities. These issues are of major importance for tourism companies as they play a vital role in the economic welfare of many countries around the world. Although the tourism in dustry has helped many countries around the world to achieve a high-level economic growth and sustainability, it is not the complete picture as it has also created many problems for indigenous communities around the world. These problems at first were seemed in isolation and were considered local issues but in a wider perspective, these problems directly or indirectly impact everyone around the globe.

The industry needs to realize this and take responsibility for their actions. (Logar (2010), Idahosa (2019)) states that the tourism industry is considered as the backbone of many third world countries but the malpractices of tourism companies create more social and economic problems for the host countries than the revenues they bring with them. These problems mainly relate to the exploitation of natural resources, health issues, and cultural degradation. Only a few of the countries have formulated legal regulations to curb the negative impact of this industry. In the case of the overall corporate sector the compliance with CSR mainly results from the stakeholder's pressure and this is mostly achieved by following international standards and obtaining certification, these practices are seldom adopted by the tourism industry in general. Levy and Park (2011) hold that to sustain the corporate and financial growth the tourism industry needs to consider corporate social responsibility as the cornerstone of their corporate policies. Chen and Wang (2011) also endorse this philosophy followed by researchers such as (Benavides et al., 2014; Kang et al., 2007). Butler (1980) mainly raised the importance of inculcating CSR activities as part of the overall objectives of tourism companies. His research was followed by (Tosun, 1998) have stressed on the importance of CSR for the industry. Their findings were further endorsed by the researches (Bonilla et al., 2014; Lee et.al 2013; Weaver, 20016).

Even though there are volumes of research on the topic, but the main issue seems to lack of reluctance on behalf of researches to explore the relationship between CSR and the tourism industry along with the impact of the incorporation of social responsibility as the cornerstone of their overall business policy, in terms of the tourism industry. There is very limited research on the impact of such policies on the sustainability and growth of this industry. According to Jones et al. (2016); Sheldon and park (2011)the main reasons periodic growth of research on this topic mainly relates to facts that tourism has a deep impact on the environmental resources and as a consequence of the growth of tourism industry many socio-economic issues have arisen, which have brought the sustainability of this industry in question. Thus, many researchers started to focus on this topic as they tended to explore the impact of widely accepted practices of this industry on the natural resources, cultural issues, and long term economic impact of this industry on the indigenous communities and host countries. These researchers not only explored the positive impact of the tourism industry but also explored the adverse impacts brought by the growth and development of the tourism industry (Nicholas and Thapa, 2013).

* Corresponding author 
Aronsson (2000) had also criticized the tourism industry for not following the international CSR standards. He puts forth the example of "eco-labeling" " which is increasingly becoming the norm in the hotel industry in developed nations. At the same time, he argues that the tourism industry whether just eco-labeling relinquishes the industry from the CSR, given the ecological, social, and economic problems caused by this industry. He further adds that "eco-labeling" is still a voluntary practice and cannot be considered as an alternative for CSR as a whole. All through the body of literature on CSR is considerable but the still the academics do not have any consensus on the universal standard to measure CSR performance in any industry in particular. In addition to this one fact remains prevalent that the tourism industry needs to acknowledge the social, ecological, and economic issues of the indigenous communities and can be financially and economically viable at the same time. According to Edgell Sr (2019), the tourism industry can develop the tourism programs in such way that tourists are not only educated about the indigenous communities cultural, ecological and social values but also manage tourism in such way that it not only benefits indigenous communities economically but also preserves the environment and social fabric of the communities. This easily is done by adopting and following CSR practices. The studies on the relationship between CSR and tourism industry, such as (Aragon-Correa et al., 2015, Coles et al., 2014) were mainly focused on the perspective of the tourism companies. These studies explored different aspects of corporate performance such as profitability, ethical decision making, and political impact. de Leaniz et al. (2012) contended that the focus of these studies was the use of CSR as a tool for enhancing the corporate profile of the company and the wider stakeholders and their perspective was largely ignored. In this article, we divert the focus of attention from the above-mentioned perspective and shift the focus towards the wider stakeholders. Structure of the article is as follows: the first part contains a detailed review of existing literature on the topic mainly focusing on accountability of different stakeholders, followed by the examination of phrase "elephant in the room", which embodies the implementation of CSR guideline as discussed by Friedman (1970), in this study we also explored that impact of CSR activities on the wider economy. Afterward, we have discussed the marketing tactics that companies typically adopt to showcase their CSR activities. One of the interesting points of this study is that we have excluded the role of NGOs and government from our discussion, mainly because their academic literature on the given topic seldom discusses their role and how they contribute towards persuading companies to adopt CSR practices.

\section{MATERIALS AND METHODS}

Holcomb et al. (2007) noted that although literature and research on the impact of CSR are on the rise there is very limited literature available on the CSR from the perspective of the tourism and hospitality industry. Grine et al. (2007) further these arguments and state that the industry is directly associated with the environment and society, which are the main reasons for tourism.

\section{CSR and Society}

The main implication of CSR for society relates to the positive impact of the business on the general public as they are held responsible not only for the welfare of their businesses but also for society. Coles et al. (2014) state that in modern era companies have made artificial changes to the way they operate for them to look as if they are following CSR practices. This notion is also held earlier by (Dodds and Kuehnel, 2010) and later (Weaver, 2006) via his research further enforced the notion held by earlier researchers. This can also be seen in the industry-wide survey conducted by the official association of different industries. One such example, most relevant to our research is that of the travel industry association of America, who mostly highlight the CSR actions related to the environment and ignore the socio-economic and socio-cultural activities. Sheldon and Park (2011) state that this is done to justify their hollow efforts and to enhance their reputation. Burns and Cowlishaw (2014) point out a similar situation in the UK airline industry and (Whitfield and Dioko, 2012) state that most companies are just content to organizing summits and conferences on the environment rather than taking concrete actions.

One fact that has emerged over time relates to the accountability of companies regarding CSR activities as accountability increases the effectiveness of these activities. According to Wocke and Merwe (2007), the South African "responsible tourism" association's membership rate improved when the association improved their communication of CSR activities. Frey and George (2010) argued that even the companies who had incorporated CSR into their policy regard these activities as increasing the over cost of their operations and thus they might lose competitive advantage over their competitors. The outcome of such researches also suggests that shareholders pressure is the main reason for these companies to peruse and keep on perusing the CSR activities. Preferably CSR should be measured by incorporating the requirements of stakeholders such as the general public, the socio-economic environment in which the business operates, but in reality, this seldom happens (Martinez et al., 2013). One such issue is pointed out by (Leung and Snell, 2017) of Macao. In Macao, the gambling industry has seen tremendous growth and the companies operating the casinos to the figuratively take up social activities, as they always point out the positive impact of this industry on the local economy, but ignored wider social issues caused by gambling such as addiction. Chang and Yeh (2016) further the above-stated notion and state that even the stakeholders of the CSR do not consider it as the primary responsibility of business to carry out such activities. The researchers concluded this after they researched Taiwan's airport series where they found that passengers were more concerned about the security and service quality rather than the treatment of employees or environmental damages caused by airport operators. The customers generally believe that the long-term financial sustainability of the business is more important than that of their CSR programs (Martínez et al., 2013). Bonilla-Priego et al. (2014) hold CSR reports to be a vital tool for measuring socially responsible actions of any organization. This notion is also backed (Guix et al., 2018) but at the same time, they state that in terms of tourism industry only $36 \%$ of largest hotel chains only $15 \%$ of the cruise companies issue reports which have any meaningful information regarding environmental, economic and cultural information. When it comes to accounting for CSR there seems to lack of single or acceptable standards as pointed out by (Holcomb et al., 2007, Bonilla-Priego et al., 2014). This issue allows companies to exaggerate the actual CSR activities and the rift appears amongst the reported activities and actual activities undertaken, thus undermining the quality of reporting (Garay and Font, 2012). The compromise on the quality of reporting not only impacts the shareholders but also the stakeholders such as suppliers, employees, and other stakeholders (Castelao et al., 2014). Garay and Font (2012) sate that the major cause can be attributed to the fact that these reports are reflective of the priorities of the company rather than those of its stakeholders.

The two most influential article reading accountability of stakeholders are as follows. The study by Ringham and Miles (2018) focuses on the "marginal" or minimum level of CSR activities which stakeholders expect to be carried out by any company operating in their economy, as they perceive the company to be accountable in this respect. This mainly depends upon the nature and scope of business. In the case of the industry in question, most of the big hotel chains do not report or include their franchised business and cite a lack of control over them when it comes to CSR activities even though they have a significant financial stake in them. Meanwhile the public expect them to be included (Melissen et al., 2016. In this context, the airline industry even has narrowed down definition CSR for their selves, by ignoring the priorities and concerns of stakeholders (Ringham and Miles, 2018). The second article is by Guix et al. (2018) which explores the opaqueness of CSR reporting, with their focus on hotel chains. These chains mostly ignore the requirement of stakeholders when it comes to CSR activities and the reporting can mainly be considered as a source of publicity rather than having an actual impact.

"Ecolabelling" is a voluntary method of environmental performance certification and labelling that is practiced around the world. An ecolabel identifies products or services proven environmentally preferable overall, within a specific product or service category" https://globalecolabelling.net/what-is-eco-labelling/ 


\section{CSR and Economy}

Although CSR has many dimensions the most important one is economic, as it refers to how economic resources are disseminated within the society, in this perspective social responsibility includes the distribution of resources from the perspective of all the major stakeholders such as consumers, human resource of company, environment, the competitors of business and society in general. As the economy of any country is deeply affected by the power held by the business over the resources of the country. The interrelationship between the environments has a great impact on the economy. Environmental concerns such as pollution impacts society. The major business may exploit the natural and human resources of the country to breaking point and move their operation to other count ries if these concerns are not properly addressed. Steven Covey, who authored the influential book titled "The Habits of Highly Effective People", held that consumers' concerns are of great importance for companies' future financial stability. He states that disregarding consumer concern is a sign of internal strife and weakness for a company which results in the production of low-quality goods and services, which in turn results in a lack of customer loyalty and low profitability. From the perspective of the employees, the economic impact of businesses is even more telling. For them, major concerns relate to the provision of equal opportunities, diversity in the workplace, their privacy, and health and safety policies along with the salary difference of top management and general employees and their accountability.

\section{CSR and consumers}

In present times customers also place importance on the socially responsible actions of companies, such as the carbon footprint of companies their environment-friendly policies, the working environment provided by these companies for human resource avoidance of child labor (Chafe and Honey, 2005). These issues are considered by tourists and travelers. The people take into account the actual impact of social activities performed by tourism companies and if they deem them to be making an actual impact than they reward them by increasing the frequency of their tractions with them. They are also quick to realize if the activities are only marketing gimmick (Becker-Olsen et al., 2006). Becker-Olsen et al. (2006) state that even though the primary concern of the customers is the quality of goods and services, these activities may provide business with a competitive edge. In the case of tourists, the priorities are not similar as they are varying from group to group. The tourists who are nature lovers are more to place importance on the conservation efforts of companies and at the same time, the other might consider community-based programs to be more important (McGehee et al. 2009). Another factor might be the age of the group as younger people place more importance on social activities as compared to old ones. The study by Nielsen Company (2012) also backed these claims, who added that younger customers are more willing to pay an extra cost if the product is of a socially responsible company.

\section{CSR and marketing}

If we analyze the market for ethical consumers or people who prefer the ethically sourced product, it was very limited almost a decade ago. The market was considered a niche (Crane, 2010). Nowadays it has grown to be one of the fastest-growing markets and businesses have to prove the source of the products (Crane, 2010). Edgell sr. (2019) states that this phenomenon has also penetrated the international tourism industry and nowadays the companies are compelled by consumers to provide CSR reports and social audits. The tourist, in general, is becoming more sensitive to social issues. (Davies and Crane (2010), Crane (2010) explains that although consumer pressure is one of the main motives for companies to conduct CSR activities the extant and their impact still needs to be explored. With time the tourism industry realized the marketing potential of this and created brands such as eco-traveling, eco-tourism, as they realized "Green" has become fashionable (Wight, 1996). Mowforth and Munt (2015) also endorses this view. Barone et al. (2000) state that companies have started to use CSR as a marketing tool to increase the overall sale and image of companies, this opinion is also endorsed by (Stokes et al., 2013). Such a marketing campaign is known as social marketing (Vlachos et al., 2010). This social marketing has become a field on its own and the only reason for discussing it was to provide a basic introduction to readers about the concept. Nowadays the marketing professionals specialized in the tourism industry are well aware of these facts and preferences of potential and present customers. So they place more importance on this aspect of marketing while research is continuously conducted on this topic. Horner and Swarbrooke, 2016 hold that to be financially viable companies need to maximize profit from each customer and at present high competition applies that customers are the core around which the companies need to construct their policies and it is reflected in the culture of modern any organization. Now days, transaction with customer is considered as exchange under customer relationship services. The success in this field is considered as achievement of customer satisfaction, their retention by offering them high level of customer services.

\section{RESULTS AND DISCUSSION}

Many less-developed nations have a serious problem of lack of planning related to tourism, so these nations should develop tourism ministries with clear objectives and goals. For the enhancement of sustainable tourism development in developing countries, there should be a focus on those elements which can put an impact on the society of developing countries. Corporate social responsibility means that firm is more apparent and responsible to stakeholders and investors to avoid risk and customers to protract more sustainable businesses which will lead to multiple effects. With the advent of the $21^{\text {st }}$ century, CSR has gained importance and in the case of the tourism industry, it is no longer a requirement but has become a norm. Nowadays it is considered pivotal, and the policies ranging from the strategic to operational level are made keeping CSR in mind. The tourism companies have come under pressure from their customers and other stakeholders to renounce previous anti-environment and anti-social activities in favor of new sustainable eco-friendly activities. At the same time, governments and regulators around the world are pressuring companies to adopt a more transparent social reporting system. In this regards governments have started rewarding companies with eco-friendly policies by providing tax incentives and subsidies (Vollebregt, 2012).

\section{CONCLUSION AND FUTURE RESEARCH}

This research was carried out from the perspective of stakeholders and how CSR literature became a vital part of academic literature relating to the tourism industry. The gaps in the existing body of literature on the topic were also identified. The main contributions of the study are an examination of accountability related to CSR, both in terms of social reporting and quality of these reports (Guix et al., 2018, Ringham and Miles, 2018). The second contribution is the analysis of the actual impact of CSR activities on the economy and community. The third main contribution is the examination of the literature regarding the role of the consumers in forcing companies to adopt socially responsible activities and contribute towards the betterment of the environment and the last contribution relates to raising awareness of reader regarding the phenomena of social marketing by providing a practical and brief introduction.

We have deliberately ignored the role of government stakeholders such as suppliers and NGOs. The main reason is that their role has largely been researched and usually overshadows the role of less talked about stakeholders. Although the industry in question at the moment might not face the pressures faced bother industries but still is susceptible to these pressures in the coming future. 


\section{REFERENCES}

Aragon-Correa, J.A., Martin-Tapia, I., \& de la Torre-Ruiz, J. (2015). Sustainability issues and hospitality and tourism firms' strategies. International Journal of Contemporary Hospitality Management, 27(3), 498-522.

Aronsson, L. (2000). The development of sustainable tourism. Continuum tourism.

Barone, M.J., Miyazaki, A.D., \& Taylor, K.A. (2000). The influence of cause-related marketing on consumer choice: does one good turn deserve another? Journal of the Academy of Marketing Science, 28(2), 248-262.

Becker-Olsen, K.L., Cudmore, B.A., \& Hill, R.P. (2006). The impact of perceived corporate social responsibility on consumer behavior. Journal of Business Research, 59(1), 46-53.

Benavides-Velasco, C.A., Quintana-García, C., \& Marchante-Lara, M. (2014). Total quality management, corporate social responsibility and performance in the hotel industry. International Journal of Hospitality Management, 41, 77-87.

Bonilla-Priego, M.J., Font, X., \& del Rosario Pacheco-Olivares, M. (2014). Corporate sustainability reporting index and baseline data for the cruise industry. Tourism Management, 44, 149-160.

Burns, P.M., \& Cowlishaw, C. (2014). Climate change discourses: How UK airlines communicate their case to the public. Journal of Sustainable Tourism, 22(5), 750-767.

Butler, R.W. (1980). The concept of a tourist area cycle of evolution: implications for management of resources. Canadian Geographer/Le Géographe canadien, 24, 5-12.

Castelao, L.O., Rico, E.J.C., \& López, F.J.Ó. (2014). Recuperación e posta en produción de terras abandonadas: a visión do sector vacún leiteiro de Galicia como demandantes no mercado de terras. Recursos Rurais (10).

Chafe, Z., \& Honey, M. (2005). Consumer demand and operator support for socially and environmentally responsible tourism. Center on Ecotourism and Sustainable Development, $15 \mathrm{p}$.

Chang, Y.H., \& Yeh, C.H. (2016). Managing corporate social responsibility strategies of airports: The case of Taiwan's Taoyuan International Airport Corporation. Transportation Research Part A: Policy and Practice, 92, 338-348.

Chen, H., \& Wang, X. (2011). Corporate social responsibility and corporate financial performance in China: an empirical research from Chinese firms. Corporate Governance. The international journal of business in society, 11(4), 361-370.

Coles, T., Fenclova, E., \& Dinan, C. (2014). Corporate social responsibility reporting among European low-fares airlines: challenges for the examination and development of sustainable mobilities. Journal of Sustainable Tourism, 22(1), 69-88.

Crane, D. (2010). Environmental change and the future of consumption: Implications for consumer identity. Anuario filosófico, 43(2), 353-353.

Davies, I.A., \& Crane, A. (2010). Corporate social responsibility in small-and medium-size enterprises: investigating employee engagement in fair trade companies. Business Ethics. A European Review, 19(2), 126-139.

de Leaniz, G., Perez, L., \& del Bosque, R. (2012). Analysis of the corporate social responsibility practice in the tourism sector: case study. Cuadernos de Turismo, 30,309-312.

Dodds, R., \& Kuehnel, J. (2010). CSR among Canadian mass tour operators: good awareness but little action. International Journal of Contemporary Hospitality Management.

Edgell Sr, D. L. (2019). Managing sustainable tourism: A legacy for the future. Routledge, $290 \mathrm{p}$.

Frey, N., \& George, R. (2010). Responsible tourism management: The missing link between business owners' at titudes and behaviour in the Cape Town tourism industry. Tourism Management, 31(5), 621-628.

Friedman, M. (1970). The Social Responsibility of Business Is to Increase Its Profits', New Cork Times Magazine, Sept. 13.

Garay, L., \& Font, X. (2012). Doing good to do well? Corporate social responsibility reasons, practices and impacts in small and medium accommodation enterprises. International Journal of Hospitality Management, 31(2), 329-337.

Grine, F.E., Bailey, R.M., Harvati, K., Nathan, R.P., Morris, A.G., Henderson, G.M., \& Pike, A.W. (2007). Late Pleistocene human skull from Hofmeyr, South Africa, and modern human origins. Science, 315(5809), 226-229.

Guix, M., Bonilla-Priego, M.J., \& Font, X. (2018). The process of sustainability reporting in international hotel groups: an analysis of stakeholder inclusiveness, materiality and responsiveness. Journal of Sustainable Tourism, 26(7), 1063-1084.

Holcomb, J.L., Upchurch, R.S., \& Okumus, F. (2007). Corporate social responsibility: what are top hotel companies reporting? International Journal of Contemporary Hospitality Management, 19(6), 461-475.

Horner, S., \& Swarbrooke, J. (2016). Consumer behaviour in tourism. Routledge, 446 p.

Idahosa, L. (2019). Understanding environmental sustainability, corporate social responsibility and responsible tourism in literature vs practice. GeoJournal of Tourism and Geosites, 26(3), 956-973.

Jones, P., Hillier, D., \& Comfort, D. (2016). Sustainability in the hospitality industry. International Journal of Contemporary Hospitality Management, $28(1), 36-67$.

Kang, H., Cheng, M., \& Gray, S.J. (2007). Corporate governance and board composition: Diversity and independence of Australian boards. Corporate governance: an international review, 15(2), 194-207.

Lee, J.W., \& Brahmasrene, T. (2013). Investigating the influence of tourism on economic growth and carbon emissions: Evidence from panel analysis of the European Union. Tourism Management, 38, 69-76.

Leung, T.C.H., \& Snell, R.S. (2017). Attraction or distraction? Corporate social responsibility in Macao's gambling industry. Journal of Business Ethics, 145(3), 637-658.

Levy, S.E., \& Park, S.Y. (2011). An analysis of CSR activities in the lodging industry. Journal of Hospitality and Tourism management, 18(1), 147-154.

Logar, I. (2010). Sustainable tourism management in Crikvenica, Croatia: An assessment of policy instruments. Tourism Management, 31 (1), $125-135$.

Martínez, P., Pérez, A., \& Rodriguez del Bosque, I. (2013). Measuring corporate social responsibility in tourism: Development and validation of an efficient measurement scale in the hospitality industry. Journal of Travel \& Tourism Marketing, 30(4), 365-385.

McGehee, N.G., \& Andereck, K. (2009). Volunteer tourism and the “voluntoured”: the case of Tijuana, Mexico. Journal of Sustainable Tourism, 17(1), 39-51.

Melissen, F., van Ginneken, R., \& Wood, R.C. (2016). Sustainability challenges and opportunities arising from the owner-operator split in hotels. International Journal of Hospitality Management, 54, 35-42.

Mowforth, M., \& Munt, I. (2015). Tourism and sustainability: Development, globalisation and new tourism in the third world. Routledge.

Nicholas, L., \& Thapa, B. (2013). The politics of world heritage: A case study of the Pitons Management Area, St Lucia. Journal of Heritage Tourism, 8(1), 37-48.

Ringham, K., \& Miles, S. (2018). The boundary of corporate social responsibility reporting: the case of the airline industry. Journal of Sustainable Tourism, 26 (7), 1043-1062.

Sheldon, P.J., \& Park, S.-Y. (2011). An exploratory study of corporate social responsibility in the US travel industry. Journal of Travel Research, 50(4), 392-407.

Stokes, P., Larson, M., Balasubrahmanyam, S., Singh, S.K., Planken, B., Nickerson, C., \& Sahu, S. (2013). CSR across the globe: Dutch and Indian consumers' responses to CSR. International Journal of Organizational Analysis.

Tosun, C. (1998). Roots of unsustainable tourism development at the local level: The case of Urgup in Turkey. Tourism Management, 19(6), 595-610.

Vlachos, P.A., Theotokis, A., \& Panagopoulos, N.G. (2010). Sales force reactions to corporate social responsibility: Attributions, outcomes, and the mediating role of organizational trust. Industrial Marketing Management, 39(7), 1207-1218.

Vollebregt, T., Kats, L.C., \& Visser, E. (2012). Declarative specification of template-based textual editors. Paper presented at the Proceedings of the Twelfth Workshop on Language Descriptions, Tools, and Applications.

Weaver, D.B. (2006). Sustainable tourism: Theory and practice. Routledge.

Whitfield, J., \& Dioko, L.A. (2012). Measuring and examining the relevance of discretionary corporate social responsibility in tourism: Some preliminary evidence from the UK conference sector. Journal of Travel Research, 51(3), 289-302.

Wight, P.A. (1996). North American ecotourists: Market profile and trip characteristics. Journal of Travel Research, 34(4), 2-10.

Wocke, A., \& Merwe, M. (2007). An investigation into responsible tourism practices in the South African hotel industry. South African Journal of Business Management, 38(2), 1-15. 